\title{
Tolerantie en risico-analyse bij de departementale jaarrelkeningcontrole
}

\author{
Drs. L. G. van der Tas
}

\section{Inleiding ${ }^{1}$}

Recentelijk is, ook in dit tijdschrift, een groot aantal artikelen verschenen over het controleproces bij de verschillende accountantskantoren en de toepassing van tolerantie en risico-analyse daarbij. ${ }^{2}$ In deze bijdragen staan bedrijfshuishoudingen centraal. In schril contrast daarmee staat de aandacht die wordt besteed aan de toepassing van tolerantie en risico-analyse bij de controle van jaarrekeningen in de publieke sector. In de praktijk blijkt namelijk dat de oplossingen die voor bedrijfshuishoudingen zijn gevonden niet of nauwelijks toepasbaar zijn bij de overheid, met name niet bij de centrale overheid. ${ }^{3}$ Dit wordt veroorzaakt door de verschillen in functie, structuur en inhoud van en de controle-eisen voor de departementale jaarrekening versus de jaarrekening van een bedrijfshuishouding. De problematiek wordt nog versterkt door de grote verschillen tussen de departementen onderling.

Hoewel de controle op de uitgaven en ontvangsten van het Rijk is opgedragen aan de Algemene Rekenkamer (artikel 65 Comptabiliteitswet 1976), ${ }^{4}$ steunt laatstgenoemde hierbij in belangrijke mate op de controlewerkzaamheden van de departementale accountantsdiensten (DAD's). De DAD is onder meer belast met de controle van de departementale jaarrekening. Haar taken komen voort uit artikel 26 van de Comptabiliteitswet 1976 en zijn nader uitgewerkt in het Besluit taak departementale accountantsdienst van 2 juli 1987.

Bij de DAD's wordt dan ook naarstig gezocht naar een oplossing van de problematiek rond de toe- passing van tolerantie risico-analyse bij de departementale jaarrekeningcontrole. De discussie wordt gecoördineerd door het IODAD (Interdepartementaal Overlegorgaan Departementale Accountantsdiensten) in het kader van de modernisering van de controle en de uniformering van de controleaanpak bij de rijksoverheid. Deze discussie is verre van uitgekristalliseerd. Bovendien kan nog niet worden gesproken van een schat aan ervaring met deze problematiek.

In deze bijdrage wordt getracht een overzicht te geven van de specifieke problemen die spelen inzake de toepassing van tolerantie en risico-analyse bij de departementale jaarrekeningcontrole en daarvoor oplossingen aan te dragen. Daarbij wordt in de eerste plaats ingegaan op de karakteristieken van de departementale jaarrekening, voor zover deze relevant zijn voor de discussie over tolerantie en risico-analyse. Aangegeven wordt waarom de voor bedrijfshuishoudingen gekozen oplossingen voor de hantering van toleranties niet altijd toepasbaar zijn. Vervolgens wordt geprobeerd oplossingen aan te dragen die zowel theoretisch gefundeerd als praktisch toepasbaar zijn. Een en ander is niet alleen van belang voor de DAD's, overheidsaccountants in het algemeen en de gebruikers van de departementale jaarrekening, maar tevens voor de openbare accountants, die immers in toenemende mate worden betrokken bij de departementale

Drs. L. G. van der Tas, geboren 1960; studeerde Bedriffseconomie aan de Erasmus Universiteit Rotterdam, doctoraal examen 1985, accountantsexamen 1988, was tot december 1990 als dienstplichtig vaandrig verbonden aan de afdeling vaktechniek van de Accountantsdienst van het ministerie van Defensie. 


\section{MAB}

jaarrekeningcontrole, hetzij in de vorm van uitbesteding van een deel van de controle, hetzij in de vorm van 'joint audits'.

\section{De departementale jaarrekening}

\subsection{Inleiding}

Onderstaand wordt zeer beknopt ingegaan op de karakteristieken van de departementale jaarrekening. De discussie blijt beperkt tot de verschillen tussen de departementale jaarrekening en de jaarrekening van bedrijfshuishoudingen voor zover deze van belang zijn voor de hantering van tolerantie en risico-analyse bij de controle.

\subsection{Functie}

De departementale jaarrekening geeft onder meer aan hoeveel is uitgegeven, hoeveel aan verplichtingen is aangegaan en hoeveel aan ontvangsten is gerealiseerd. Zij vormt daarmee de verantwoording van de departementsleiding aan het parlement over de begrotingsuitvoering in het betreffende boekjaar. De jaarrekening kan dan ook niet los worden gezien van de door het parlement goedgekeurde begroting waarin per begrotingsartikel is vastgelegd hoeveel mag worden uitgegeven, respectievelijk aan verplichtingen mag worden aangegaan en hoeveel begroot wordt aan ontvangsten. Elk van deze begrotingsartikelen representeert een beleidspunt. Met behulp van de begroting stuurt het parlement dus de aanwending van de middelen die de overheid ter beschikking staan en de wijze waarop deze middelen moeten worden verkregen. De middelen worden te voren bepaald en verdeeld over de beleidspunten. De departementale jaarrekening geeft aan hoeveel middelen elk van de beleidspunten (begrotingsartikelen) daadwerkelijk zijn besteed en geven dus een indicatie van de mate waarin de middelen conform het voorgestane beleid zijn verdeeld. Dit betekent dat elk van de begrotingsartikelen een zelfstandige betekenis heeft.

Het bovenstaande geeft aan dat de departementale jaarrekening zich essentieel onderscheidt van de jaarrekening van een bedrijfshuishouding. In de eerste plaats heeft de jaarrekening van een bedrijfshuishouding niet alleen een verantwoordingsfunctie, maar tevens een informatiefunctie, waardoor gebruikers zich een oordeel moeten kunnen vormen omtrent bijvoorbeeld de rentabiliteit, continuitteit, liquiditeit en solvabiliteit van de huishouding, ook in de toekomst, voor zover dit door een retrospectief verantwoordingsstuk als de jaarrekening kan worden verschaft. In de tweede plaats onderscheidt de verantwoordingsfunctie van de jaarrekening van een bedrijfshuishouding zich van de verantwoordingsfunctie van de departementale jaarrekening. Bij een bedrijfshuishouding immers is de financiële verantwoording erop gericht aan te geven wat met de aangewende middelen aan opbrengsten is gegenereerd of hoeveel middelen zijn aangewend om het gestelde doel te bereiken, niet op welke wijze dit is gebeurd. Sluitstukken van deze jaarrekening vormen het resultaat en het eigen vermogen. De samenstelling van de activa en passiva alsmede van de baten en lasten, dus de individuele posten van de jaarrekening kunnen daarbij van belang zijn (onder meer voor het bepalen van de liquiditeit, solvabiliteit, relatie tussen het resultaat uit gewone bedrijfsactiviteiten en het buitengewone resultaat), maar zij hebben niet het belang van de individuele posten van de departementale jaarrekening. Bovendien is er geen strakke relatie tussen de individuele posten en het gevoerde beleid. De functie van de individuele posten van de departementale jaarrekening (begrotingsartikelen) is een geheel andere dan die van de individuele posten van de jaarrekening van een bedrijfshuishouding. De samenstelling van de aangegane verplichtingen, de uitgaven en de ontvangsten is daar nu juist essentieel. Het geeft immers aan of het departement de middelen conform het door het parlement voorgestane beleid heeft aangewend.

Het afleggen van verantwoording komt voort uit een delegatie van bevoegdheden en de terbeschikkingstelling van middelen aan de gedelegeerde, verantwoordingsplichtige. Wellicht kan het verschil in functie van de beide soorten jaarrekeningen kort (en enigszins gechargeerd) als volgt worden getypeerd. De delegatie van bevoegdheden aan de leiding van een bedrijfs- 


\section{MAB}

huishouding is een generieke, dat wil zeggen dat de doelstellingen/taken worden opgegeven en de middelen ter beschikking gesteld zonder verder aan te geven op welke wijze de doelstellingen moeten worden behaald. Voor zover bij de delegatie al wordt gespecificeerd hoe de doelstellingen moeten worden gehaald, zal dit niet gebeuren in de vorm van een begrote balans en winsten verliesrekening, maar in de vorm van het formuleren van randvoorwaarden zoals arbeidsomstandigheden, werkgelegenheid, milieu-eisen, enzovoort. De jaarrekening geeft weer in hoeverre deze doelstellingen zijn gehaald en op welke wijze dit is geschied. In de centrale overheidssfeer worden niet alleen middelen ter beschikking gesteld, maar wordt tevens aangegeven op welke wijze deze middelen moeten worden aangewend. De jaarrekening geeft aan of inderdaad de ter beschikking gestelde middelen op de voorgestane wijze over de inspanningen ter bereiking van de verschillende doeleinden zijn gealloceerd.

Het gevolg daarvan voor de toepassing van toleranties is dat bij de departementale jaarrekening door de gebruikers een geringere afwijking zal worden getolereerd op de individuele posten van de jaarrekening (bedragen bij de verschillende begrotingsartikelen) dan bij de jaarrekening van een bedrijfshuishouding. Dit wordt bevestigd door het feit dat de behandeling van de jaarrekening in het parlement plaatsvindt per begrotingsartikel. De bedragen voor elk van de begrotingsartikelen verschillen qua omvang aanzienlijk. Een absoluut gezien kleine, maar relatief gezien grote afwijking bij een kleine post van de jaarrekening zal daarom al snel bij de jaarrekening van een bedrijfshuishouding als niet materieel ten opzichte van het totaal worden aangemerkt, terwijl dit bij de departementale jaarrekening wel als materieel wordt ervaren, omdat het aangeeft dat de middelen op andere wijze zijn aangewend dan voorgestaan door het parlement.

\subsection{Structuur en inhoud}

De departementale jaarrekening is opgesteld volgens een mengvorm van het systeem van dubbelboekhouden en de kameraalstijl. Verantwoording vindt in principe op kasbasis plaats, maar wij vin- den bijvoorbeeld tevens het bedrag aan aangegane verplichtingen en de stand verplichtingen per ultimo boekjaar terug.

Aan het verrichten van een uitgave gaat meestal een tweetal fasen vooraf, namelijk het reserveren van een stukje van de begrotingsruimte op het betreffende begrotingsartikel en vervolgens het aangaan van een verplichting op het begrotingsartikel. Het kan echter tevens voorkomen dat een uitgave niet wordt voorafgegaan door het registreren van een aangegane verplichting.

Uitgaven en ontvangsten zijn niet identiek aan uitgaande en inkomende kasstromen. Van een uitgave wordt gesproken indien een uitgaande kasstroom ten laste van een uitgave-artikel wordt gebracht. Van een ontvangst wordt gesproken indien een inkomende kasstroom ten gunste van een middelenartikel wordt gebracht. Naast de op de begrotingsartikelen geboekte uitgaven en ontvangsten vinden tevens overige kasstromen plaats (bijvoorbeeld betalingen ten behoeve van derden) die worden geboekt op zogenaamde derdenrekeningen. De departementale jaarrekening bestaat uit een aantal overzichten, namelijk:

- de totalen per begrotingsartikel van de in het boekjaar aangegane verplichtingen, met de vermelding in hoeverre deze in het boekjaar of in een later jaar tot uitgaven hebben geleid, respectievelijk zullen leiden;

- de totalen per begrotingsartikel van de in het boekjaar verrichte uitgaven;

- de stand verplichtingen per ultimo boekjaar. Dit is het saldo van de stand begin boekjaar plus aangegane verplichtingen minus de op deze verplichtingen verrichte uitgaven en minus de vervallen verplichtingen;

- de stand betaalde voorschotten. Voorschotten worden op het moment van betaling geregistreerd als uitgaven op het betreffende begrotingsartikel. De stand voorschotten wordt extra-comptabel bijgehouden. Op het moment van afwikkeling van de verplichting wordt het voorschot weggeboekt en het eventuele verschil tussen de totale uitgave en het reeds betaalde voorschot op het uitgave-artikel geboekt;

- de totalen per begrotingsartikel van de ontvangsten in het betreffende boekjaar; 


\section{MAB}

- de verstrekte garanties;

- de vorderingen;

- de deelneming, en

- de saldi-balans. Deze moet niet worden verward met de saldi-balans bij bedrijfshuishoudingen. Het betreft hier slechts een overzicht van naar het volgende begrotingsjaar over te brengen financiële posten, zoals de rekeningcourant verhouding met het ministerie van Financiën, de openstaande ten behoeve van derden verrichte betalingen, enzovoort.

Uit het voorgaande blijkt dat de structuur en inhoud van de departementale jaarrekening niet vergelijkbaar is met de jaarrekening van een bedrijfshuishouding. Er is geen volledig systeem van dubbelboekhouden. Slechts zelden is er sprake van een geld-goederen beweging. En met name zijn niet altijd de verbanden aanwezig tussen de verschillende overzichten, zoals deze wel bestaan tussen de op basis van het systeem van dubbelboekhouden opgestelde balans en winsten verliesrekening van een bedrijfshuishouding waar immers het saldo winst in beide staten gelijk is.

\subsection{Controle-eisen}

De jaarrekening van een bedrijfshuishouding, voor zover deze is onderworpen aan Titel 9 BW 2 , moet een getrouw beeld geven van het vermogen en het resultaat van de huishouding over het boekjaar. Wij zullen dit aanduiden met de getrouwheidseis. Dit betekent dat de gebeurtenissen en transacties gedurende het boekjaar juist, volledig en tijdig in de jaarrekening moeten zijn verwerkt. De jaarrekeningcontrole moet op deze getrouwheidseis zijn gericht. De getrouwheidseis geldt uiteraard ook voor de departementale jaarrekening. Daarnaast echter is nog een tweede eis gesteld aan de departementale jaarrekening, namelijk de rechtmatigheidseis. Gecontroleerd moet worden of (artikel 66 Comptabiliteitswet 1976): ${ }^{5}$

a de uitgaaf valt binnen de omschrijving van het begrotingsartikel, waarop zij is aangewezen; voorts of zij behoort tot het dienstjaar, ten laste waarvan zij wordt gebracht, en het begrotingsartikel toereikend is; b de schuldvordering niet was verjaard;

c of de overgelegde bewijsstukken naar waarheid zijn opgemaakt en voldoende zijn om het recht van de schuldeiser te staven;

$d$ of in het algemeen geen wettelijk voorschrift de uitgaaf in de weg stond.'

Het is van belang op te merken dat de twee eisen betrekking hebben op verschillende objecten. Gaat het bij de getrouwheidseis om de weergave van het financiële beheer in de jaarrekening, bij de rechtmatigheidseisen gaat het om de rechtmatigheid van het financiële beheer zelve. Dit kan als volgt grafisch worden weergegeven:

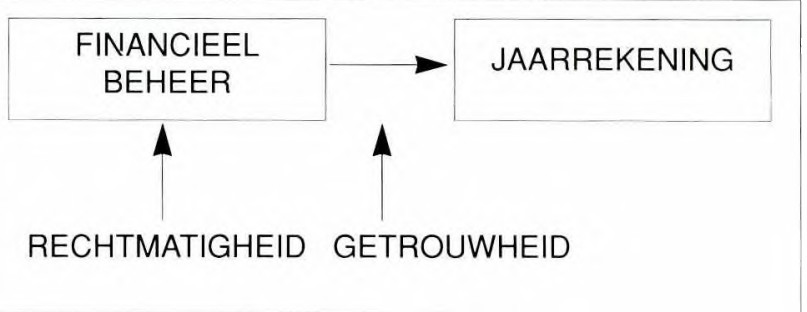

De rechtmatigheidseis geldt niet voor de jaarrekening van een bedrijfshuishouding, hoewel van de acountant een steeds grotere rol wordt verwacht in het kader van de rechtmatigheid van de in de jaarrekening weergegeven transacties en gebeurtenissen (te denken valt hierbij bijvoorbeeld aan de rapportering omtrent geconstateerde fraude). Bovendien zal de accountant beducht zijn op mogelijke financiële consequenties van onwetmatig of onrechtmatig handelen van de onderneming. De extra controle-eis die aan de departementale jaarrekening wordt gesteld heeft belangrijke consequenties voor de hantering van toleranties bij de controle. De gebruiker van de departementale jaarrekening zal, ceteris paribus, een geconstateerde onrechtmatigheid van $f \times,-$ belangrijker vinden dan een getrouwheidsfout van $f \times,-$. Met andere woorden de te hanteren tolerantie bij het eindoordeel verschilt, afhankelijk van het feit of er sprake is van een getrouwheidsfout, dan wel een rechtmatigheidsfout. Omdat vrijwel altijd de controle op de getrouwheid en rechtmatigheid tegelijkertijd c.q. geintegreerd plaatsvindt, moet bij de controle de laagste van de twee toleranties worden 


\section{MAB}

gehanteerd. Bij het eindoordeel omtrent de verantwoording daarentegen, zal het verschil in tolerantie wel een rol spelen en zullen rechtmatigheidsverschillen eerder materieel zijn dan getrouwheidsverschillen.

Bij de evaluatie van de gevonden fouten bij de jaarrekeningcontrole en de vergelijking met de tolerantie moeten getrouwheidsverschillen anders worden behandeld dan rechtmatigheidsverschillen. Niet alleen zullen rechtmatigheidsverschillen zwaarder wegen dan getrouwheidsverschillen, maar ook moet worden geconstateerd dat rechtmatigheidsverschillen elkaar nooit kunnen compenseren terwijl dit bij getrouwheidsverschillen soms wel het geval is. De onrechtmatigheid van een ten onrechte betaalde gulden wordt niet weggenomen door een ten onrechte niet betaalde gulden, zelfs niet indien beide fouten in hetzelfde begrotingsartikel zitten. Deze fouten kunnen dus niet worden gesaldeerd, maar moeten worden opgeteld. Voor getrouwheidsverschillen daarentegen geldt dat indien zich binnen een begrotingsartikel twee tegengestelde fouten voordoen, deze wel kunnen worden gecompenseerd omdat per saldo wel een getrouwe weergave plaatsvindt.

\subsection{Risico's}

Bij de bepaling van de aard en omvang van de controlewerkzaamheden door de accountant zal hij zich onder meer laten leiden door de omvang van de risico's. Bij de controle van de verantwoording van een bedrijfshuishouding betreft dit het risico dat zich in de verantwoording een of meer fouten bevinden met een totale financiële omvang die groter is dan de gehanteerde tolerantie. Dit geldt uiteraard ook voor de departementale jaarrekening. Bij de controle van de departementale jaarrekening echter, moet de accountant daarnaast rekening houden met politieke risico's. Bepaalde uitgaven of andere elementen van de verantwoording kunnen politiek gevoeliger zijn dan andere. Politieke gevoeligheid hangt niet of nauwelijks samen met de financiële omvang van het betreffende element, maar met de aard ervan. Door relatief zeer geringe bedragen kunnen politieke problemen ontstaan, bijvoorbeeld indien het de privacy van mensen betreft, indien het de voorbeeldfunctie van politici regardeert (een minister die in een paar duizend gulden te dure dienstauto rijdt), indien het gepaard gaat met heffingen, indien de sociaal zwakkeren betrokken zijn, indien mensen worden geconfronteerd met vrijheidsbelemmeringen (spitsvignet, verplichte OV-jaarkaart), enzovoort. Dit betekent dat de acountant zich bij de bepaling van de aard en omvang van de controlewerkzaamheden ten aanzien van de verschillende elementen van de verantwoording niet alleen laat leiden door de financiële consequenties, maar tevens door de politieke consequenties van een eventuele fout in de verschillende elementen van de verantwoording. Bij politiek gevoelige begrotingsartikelen zal de accountant meer willen doen dan bij minder gevoelige begrotingsartikelen. Vanwege het bijzondere karakter van politieke risico, past zij niet in het bestaande risico-analysemodel. Als de accountant dus rekening wil houden met deze politieke gevoeligheden, kan hij dit slechts bereiken door voor deze begrotingsartikelen het accountantscontrolerisico (zie 6), dan wel de tolerantie lager te stellen, zodat automatisch meer controle-inspanningen aan dit element worden besteed.

\section{Een of meer toleranties?}

Doel van de jaarrekeningcontrole is het afgeven van een accountantsverklaring bij de jaarrekening. Bij dit uiteindelijke oordeel omtrent de departementale jaarrekening moet het totaal van de bij de controle aangetroffen fouten worden afgewogen ten opzichte van de bij de jaarrekening te hanteren tolerantie. Wij zullen deze tolerantie in navolging van het Limperg Instituut (1990, p. 85) aanduiden met jaarrekeningtolerantie. De hoogte van deze jaarrekeningtolerantie zal afhankelijk zijn van de grootte en samenstelling van de uiteindelijk gerealiseerde jaarrekening. Deze jaarrekening is pas na afloop van het begrotingsjaar bekend zodat de hoogte van de jaarrekeningtolerantie aan het begin van de controle nog niet kan worden vastgesteld. De realisatie kan immers afwijken van de begroting van het boekjaar. Bovendien wordt de begroting gedu- 


\section{MAB}

rende het begrotingsjaar enkele malen bijgesteld. Toch vinden gedurende het boekjaar reeds controles plaats waarbij een bepaalde tolerantie moet worden gehanteerd. Daarom moet bij het begin van de controle een tolerantie worden vastgesteld ten behoeve van planningsdoeleinden en als voorlopige basis voor de interim-controles. Wij zullen deze (in navolging van het Limperg Instituut, 1990, p. 86) aanduiden als controletolerantie.

Uit voorzichtigheidsoverwegingen kan rekening worden gehouden met een veiligheidsmarge in de tolerantie ten behoeve van de controle. Dit leidt tot een controletolerantie, die onder de verwachte jaarrekeningtolerantie ligt. Hiermee kan bovendien worden voorkomen dat eventuele afwijkingen naar beneden van de realisatiecijfers ten opzichte van de begrotingscijfers leiden tot het achteraf constateren dat de gehanteerde controletolerantie te hoog was ten opzichte van de realisatiecijfers.

De jaarrekening- en controletolerantie gelden voor de jaarrekening als geheel.

Wij zagen echter in 2.2 dat aan de individuele begrotingsartikelen van de aangegane verplichtingen, uitgaven en ontvangsten op de departementale jaarrekening een belangrijke zelfstandige betekenis moest worden toegedeeld die ver uitgaat boven het belang dat aan individuele posten van de jaarrekening van een bedrijfshuishouding wordt toegekend. Deze mondt erin uit dat de gebruiker van een departementale jaarrekening niet alleen verwacht dat de totale fout in de jaarrekening als geheel beneden een bepaalde tolerantie blijft, maar tevens dat per begrotingsartikel de daarin aangetroffen fouten niet relatief groot zijn ten opzichte van het begrotingsartikelbedrag. Wij zijn van mening dat de zelfstandige betekenis van het begrotingsartikel niet zodanig groot is dat $\mathrm{zij}$ zelfstandige objecten van controle vormen. Wel menen wij dat deze zelfstandige betekenis, zoals in 2.2 aan de orde gesteld, ertoe leidt dat naast een jaarrekening- en controletolerantie voor de jaarrekening als geheel, per begrotingsartikel een begrotingsartikeltolerantie moet worden gehanteerd. Dit betekent dat met name bij de kleinere begrotingsartikelen meer werkzaamheden zullen moeten worden verricht dan vereist indien slechts één tolerantie voor de gehele jaarrekening wordt gehanteerd. De begrotingsartikeltolerantie is afhankelijk van de financiële omvang van het begrotingsartikel, maar bijstellingen naar beneden zijn mogelijk, bijvoorbeeld wanneer de accountant een verhoogd politiek risico door middel van een verlaging van de tolerantie bij zijn controle zou willen afdekken.

Gezien het feit dat het begrotingsartikel geen zelfstandig object van controle vormt en het primair belang ligt bij de jaarrekening als geheel, kan de begrotingsartikeltolerantie relatief (ten opzichte van het begrotingsartikelbedrag) hoger zijn dan de jaarrekening- en de controletolerantie ten opzichte van de totale omvangsbasis. Wij zullen in 4 nader ingaan op deze omvangsbasis. Ter illustratie: Indien de tolerantie voor de totale jaarrekening op $1 \%$ van de totale omvang wordt gesteld, bijvoorbeeld $f 140$ miljoen op een totale jaarrekening van $f 14$ miljard, dan zal de gebruiker voor de beoordeling van één begrotingsartikel van de jaarrekening een relatieve tolerantie van meer dan $1 \%$ van het begrotingsartikelbedrag van bijvoorbeeld 100 miljoen voor ogen hebben. Hij zal dan bijvoorbeeld pas een bedrag van $5 \%$ (in dit geval 5 miljoen) van het begrotingsartikelbedrag of wellicht meer als materieel ervaren.

Bij grote begrotingsartikelen kan dit ertoe leiden dat het bedrag van de begrotingsartikeltolerantie boven het bedrag van de jaarrekeningtolerantie uitstijgt. In elk geval moet de laagste van de twee worden gehanteerd.

De accountant dient zich de nodige zekerheid te verschaffen dat een eventuele fout in een bepaald begrotingsartikel ook relatief, ten opzichte van het begrotingsbedrag, niet materieel is. Dit betekent dat niet alleen moet worden vastgesteld dat de totale fout niet boven de tolerantie voor de gehele jaarrekening uitgaat, maar moet tevens worden vastgesteld dat evenmin de (in relatieve zin hogere, maar wellicht in absolute zin lagere) tolerantie per begrotingsartikel wordt overschreden. Het gaat hier met name om het verrichten van additionele werkzaamheden bij kleinere 
begrotingsartikelen. De controle moet dus zodanig plaatsvinden dat elk begrotingsartikel wordt gecontroleerd met de laagste van de jaarrekeningtolerantie en de begrotingsartikeltolerantie.

Ter illustratie volgt onderstaand een cijfervoorbeeld. De jaarrekening 1990 van departement $X$ ziet er als volgt uit (in $f$ miljoen):

\begin{tabular}{lrrr}
\hline & $\begin{array}{r}\text { Aangegane } \\
\text { verplichtingen }\end{array}$ & Uitgaven & $\begin{array}{r}\text { Ontvang- } \\
\text { sten }\end{array}$ \\
\hline Uitgavenartikel & 200 & 400 & \\
1 & 100 & 100 & \\
2 & 10 & 10 & \\
3 & 1 & 1 & 20 \\
4 & - & & 20 \\
Middelenartikel & & & \\
1 & & & 40 \\
2 & 311 & 511 & \\
Totaal & & & \\
\hline
\end{tabular}

Stel dat de jaarrekeningtolerantie $f 5$ miljoen is en dat de begrotingsartikeltolerantie op $10 \%$ van het begrotingsartikelbedrag wordt gesteld. Dan moet bij de controle van de verschillende begrotingsartikelen de volgende toleranties worden gehanteerd (in $f$ miljoen):

\begin{tabular}{lrrr}
\hline & $\begin{array}{r}\text { Aangegane } \\
\text { verplichtingen }\end{array}$ & Uitgaven & $\begin{array}{r}\text { Ontvang- } \\
\text { sten }\end{array}$ \\
\hline Uitgavenartikel & $5^{\mathrm{a}}$ & $5^{\mathrm{a}}$ & \\
1 & $5^{\mathrm{a}}$ & $5^{\mathrm{a}}$ & \\
2 & 1 & 1 & \\
3 & 0,1 & 0,1 & \\
4 & & & \\
& & & 2 \\
Middelenartikel & & & 2 \\
2 & & & \\
\hline
\end{tabular}

a Hier is de jaarrekeningtolerantie ( $f 5$ miljoen) lager dan de begrotingsartikeltolerantie $(10 \%$ van het begrotingsartikelbedrag), dus moet de jaarrekeningtolerantie worden gehanteerd.

Met deze illustratie willen wij niet tot uitdrukking brengen dat de controle per se per begrotingsar- tikel en voor aangegane verplichtingen, uitgaven en ontvangsten afzonderlijk moet plaatsvinden. De toleranties gelden voor het eindoordeel omtrent de verantwoording.

In alle gevallen dient men zich te realiseren dat het hanteren van een fijnere maas bij deze additionele werkzaamheden bij kleinere begrotingsartikelen door middel van de begrotingsartikeltolerantie uiteraard effect heeft op de controle van de rechtmatigheid, juistheid, tijdigheid, autorisatie enzovoort, maar slechts onder bepaalde voorwaarden op de controle van de volledigheid. Er wordt wel met een grotere nauwkeurigheid vastgesteld dat op het betreffende artikel geen onjuiste of onrechtmatige boekingen zijn gepleegd, maar er wordt niet met een fijnere maas gecontroleerd of er niet nog meer op had moeten worden geboekt.

Dan zouden alle artikelen met deze fijnere maas moeten worden gecontroleerd omdat deze boekingen dan terecht zijn gekomen op een ander artikel. De voorwaarde die dan ook geldt is dat er voldoende administratief-organisatorische scheiding tussen beschikkende functies met betrekking tot de onderscheiden begrotingsartikelen is aangebracht. Er mag niet één budgethouder verantwoordelijk zijn voor verschillende begrotingsartikelen. Indien dit wel het geval is, wordt de volledigheid niet met een lagere tolerantie dan de controletolerantie gecontroleerd en moet een toevlucht worden gezocht in een begrotingsartikeltolerantie per cluster van begrotingsartikelen waartussen onvoldoende bovenbedoelde administratief-organisatorische scheiding bestaat.

\section{Basis voor de tolerantie}

De criteria voor de keuze tussen alternatieve omvangsbasis voor de bepaling van de toleranties zijn dat de basis een goede indicator van de omvang van een departement moet zijn en dat deze enigszins stabiel moet zijn over de tijd om te voorkomen dat de controlewerkzaamheden van jaar tot jaar sterk verschillen ook indien de omvang van de organisatie als zodanig niet belangrijk verandert.

Voor veel departementen zal het totaalbedrag 


\section{MAB}

aan uitgaven een goede graadmeter voor de omvang zijn. Voor het ministerie van Financiën daarentegen is dit een slechte omvangsbasis, omdat de activiteiten met name zijn gericht op de ontvangstenkant. Gezien het feit dat de jaarrekening van de verschillende departementen onderdeel uitmaken van één rekening (de rijksrekening) moet naar onze mening worden gestreefd naar een uniforme omvangsbasis voor alie departementen. In dat geval kan als omvangsbasis de som of het saldo van de ontvangsten en uitgaven worden genomen. Als alternatief biedt zich aan dat de jaarrekening- en controletolerantie bij de jaarrekening van het ministerie van Financiën worden gebaseerd op het totaalbedrag van de ontvangsten terwijl de tolerantie bij de overige ministeries wordt gebaseerd op het totaalbedrag van de uitgaven. ${ }^{7}$

De jaarrekeningtolerantie kan worden gebaseerd op de cijfers in de uiteindelijke jaarrekening. De voor planningsdoeleinden te hanteren controletolerantie, moet noodzakelijkerwijs worden gebaseerd op de realisatiecijfers van het voorafgaande begrotingsjaar of op de begroting van het te controleren boekjaar. Onze voorkeur gaat hierbij uit naar basering op de begroting van het te controleren jaar aangezien dit de beste inschatting is van de uiteindelijke realisatiecijfers. Verwacht de accountant dat de realisatiecijfers uiteindelijk hoger zullen zijn, dan levert dit geen probleem op omdat dan de controletolerantie in elk geval niet te laag is ingeschat. Bestaat bij de accountant de verwachting dat de realisatiecijfers beduidend lager zullen zijn dan de begrote, dan is een bijstelling naar beneden van de controletolerantie op zijn plaats.

Voor de begrotingsartikeltolerantie geldt het begrotingsartikelbedrag als omvangsbasis.

\section{Hoogte van de tolerantie}

De berekening van hoogte van de tolerantie uit de omvangsbasis van een departement kan plaatsvinden door middel van de toepassing van een enkelvoudig percentage of een glijdende schaal. Bij toepassing van een enkelvoudig percentage wordt slechts rekening gehouden met de relatieve omvang van de tolerantie ten opzichte van het totaal. Bij glijdende schalen, waarbij het percentage van de tolerantie vermindert naar mate de omvangsbasis groter wordt, wordt niet alleen rekening gehouden met de relatieve, maar tevens met de absolute omvang van de tolerantie. Hoe groter de tolerantie, des te belangrijker wordt het absolute bedrag, ook al is de tolerantie relatief slechts gering vergeleken bij de omvangsbasis.

Het opstellen van een glijdende schaal is een gecompliceerde en arbeidsintensieve exercitie. Voor accountantskantoren is dit niet zo'n probleem omdat de schaal gebruikt kan worden bij de veelheid van bedrijven waar de jaarrekening wordt gecontroleerd. Bij de overheid daarentegen wordt de schaal slechts enkele malen toegepast en zal de omvang van de verantwoordingen in de tijd weinig fluctueren. Hoewel de glijdende schaal toepasbaar is, lijkt het zinvoller te kiezen voor de toepassing van een enkelvoudig percentage en dit percentage eventueel naar beneden bij te stellen indien de omstandigheden (zoals de omvang van het te controleren object) dit vereisen.

Het te kiezen percentage moet naar onze mening zeer laag worden gesteld, gezien het in 2 vermelde belang van rechtmatigheid en de lage tolerantie die in dit kader door de gebruiker wordt gehanteerd. Naar onze mening moet dit percentage tussen de $0,5 \%$ en $1 \%$ van de omvangsbasis liggen. Dit doet enerzijds recht aan het maatschappelijk belang van een nauwkeurige controle op de rechtmatigheid van de overheidsbestedingen en leidt anderzijds niet tot extreem omvangrijke en daarmee inefficiënte controlewerkzaamheden bij de departementale jaarrekeningcontrole. $^{8}$

Tevens wordt hier nog de aandacht gevestigd op het in 3 gestelde omtrent de begrotingsartikeltolerantie. Daarvoor geldt een hoger percentage dan het hier genoemde.

\section{Risico-analyse}

Voor de risico-analyse kan in principe het risicoanalysemodel zoals dit ook bij bedrijfshuishou- 
dingen veelal wordt toegepast, worden gehanteerd. De risico-analyse vindt plaats per (cluster van) begrotingsartikel(en) per sub-controle-eis. Sub-controle-eisen zijn onderverdelingen van de controle-eisen getrouwheid en rechtmatigheid. Bij getrouwheid kan worden gedacht aan bijvoorbeeld volledigheid, tijdigheid en juistheid van de weergave in de jaarrekening. Bij rechtmatigheid kan worden gedacht aan autorisatie, in overeenstemming met de regelgeving, enzovoort.

In 2.5 brachten wij reeds het politiek risico aan de orde dat vanwege haar bijzondere aard niet in het risico-analysemodel past. Het rekening houden met deze politieke risico's kan dan plaatsvinden door de begrotingsartikeltolerantie bij politiek gevoelige begrotingsartikelen naar beneden bij te stellen of door het maximum geaccepteerd accountantscontrolerisico bij de politiek gevoelige (clusters van) begrotingsartikelen te verlagen.

\section{Relatie tussen tolerantie en risico-analyse}

De relatie tussen tolerantie en risico-analyse is tweeledig. In de eerste plaats wordt de inschatting van de risico's gekoppeld aan een bepaalde tolerantie/materialiteit. Het risico wordt in alle gevallen gedefinieerd als de kans dat een materiële onjuistheid ontstaat, respectievelijk niet wordt ontdekt. Sommige accountantskantoren hebben deze tolerantie in kwantitatieve zin gespecificeerd, bijvoorbeeld door de controletolerantie 'toe te rekenen' aan elementen van de verantwoording (zie Limperg Instituut, 1990, p. 91). Andere kantoren nemen deze tolerantie slechts impliciet mee bij hun risico-analyse. Bedacht dient te worden dat deze tolerantie niet moet worden verward met de begrotingsartikeltolerantie zoals ten tonele gevoerd in 3 (zie ook noot 6).

In de tweede plaats wordt de omvang van de detailcontrole bepaald door de combinatie van tolerantie en risico-analyse. Hoe hoger het aanwezige risico of hoe lager het gewenste accountantscontrolerisico of hoe lager de tolerantie, des te omvangrijker zijn de detailcontrolewerkzaamheden.

Hier wordt nog de aandacht gevestigd op de begrotingsartikeltolerantie. De omvang van de werkzaamheden per begrotingsartikel moet zijn gebaseerd op de laagste van de begrotingsartikeltolerantie en de controletolerantie.

\section{Conclusie}

In dit artikel is getracht na te gaan in hoeverre de verschillen tussen de departementale jaarrekening enerzijds en de jaarrekening in de private sector anderzijds consequenties hebben voor de toepassing van toleranties en risico-analyse bij de accountantscontrole. Gebleken is dat deze consequenties met name op het terrein van de tolerantie en in mindere mate op het terrein van de risico-analyse liggen. De consequenties voor de toepassing van toleranties zijn de andere basis voor de bepaling van de toleranties, de lage tolerantie voor rechtmatigheidsfouten, de additionele tolerantie per begrotingsartikel van de departementale jaarrekening, het eventueel rekening houden bij het bepalen van de toleranties met de politieke gevoeligheden en het verschil tussen getrouwheids- en rechtmatigheidsfouten. De consequenties voor de toepassing van risicoanalyse zijn gering. Een mogelijke implicatie is het rekening houden met politieke risico's bij het vaststellen van het accountantscontrolerisico per begrotingsartikel.

\section{Literatuur}

American Institute of Certified Public Accountants, Audits of State and Local Governmental Units, New York (NY), 1986.

Barneveld, J. H. van en L. Y. F. M. van Densen, Accountantscontrolerisico en tolerantie in onderlinge samenhang bij een (interne) accountantsdienst, $M A B$, oktober 1990, pp. 403-408.

Bent, J. van den, Financieel management bij de rijksoverheid, 's Gravenhage, 1989.

Bruin, E. D. de, Moderne controle-aanpak, AuditPlus, de controlebenadering van Deloitte Haskins \& Sells International, $M A B$, september 1989, pp. 325-331.

Buisman, J. H. en J. ten Wolde, Moderne controle-aanpak, KPMG Audit: controleproces van KPMG Klijnveld Kraayenhof \& Co, MAB, oktober 1989, pp. 388-395.

Carmichael, D. R. en W. W. Holder, Materiality considerations in Governmental Audits, CPA Journal, December 1987, pp. 103107. 


\section{MAB}

Dijk, J. F. van, De betekenis van 'materiality' voor de accountantscontrole van de jaarrekening, $M A B$, januari/ februari 1989 , pp. 6-16.

Dijk, J. F. van, Materialiteit, in: NIVRA Geschrift nr. 46 'Materialiteit bij de opstelling en de controle van de jaarrekening, februari 1989, pp. 11-70.

Emanuels, J. A. en Ph. Wallage, Het bepalen van de tolerantie in de jaarrekening, $M A B$, januari/februari 1990.

Kinds, J. H. G. en J. C. E. van Kollenburg, Moderne Controleaanpak, BDO Compass: de controlemethode van de BDO Camps Obers Groep, MAB, juni 1990, pp. 254-263.

Koolen, A. en S. Wiersma, Informatiebereidheid gemeenten tegenover Rijk maakt keurmerk accountant overbodig, Binnenlands Bestuur 15-6-1990, pp. 26-27.

Krom, J. P. J., Moderne controle-aanpak, UNICON en COCON: uit de gereedschapskist van de Nederlands Accountants Maatschap de Tombe, MAB, november 1989, pp. 462-468.

Kropatkin, Ph. en R. Forrester, The Single Audit - Independence, Materiality, and Cost-Effectiveness - Part I, CPA Journal, February 1983, pp. 10, 12, 14-16; Part II, CPA Journal, March 1983, pp. 16, 18, 20-23.

Leslie, D. A., Materiality, the concept and its application to auditing, Toronto, 1985.

Limperg Instituut, Risico's en oordeelsvorming in de accountantspraktijk, Amsterdam, 1990.

Nederlands Instituut van Registeraccountants, Vakkundige oordeelsvorming van de accountant, NIVRA Geschrift nr. 41, Amsterdam, mei 1986.

Oorschot, C. P. M. van, Materialiteit en accountantscontrolerisico bij de gemeentelijke overheid, VAS Magazine, mei/juni 1990 , nr. 5, pp. 4-8.

Tuinsma, L. F. G., Moderne controle-aanpak, Accountantscontrole bij Moret \& Limperg, MAB, november 1989, pp. 455-462.

Wolde, J. ten, Enkele beschouwingen bij risico-analyse in de accountantscontrole, MAB, september 1989, pp. 331-340.

Wolde, J. ten, Nederlandse versus Amerikaanse accountantscontrole, MAB, maart 1990, pp. 78-85.

\section{Noten}

1 Dit artikel werd geschreven op persoonlijke titel. Dank gaat uit naar L. M. Bijkerk RA, Dr. M. N. Hoogendoorn RA en Drs. B. J.
C. Viveen RA voor hun commentaar op een eerdere versie van dit artikel.

2 Zie bijvoorbeeld de serie 'Moderne controle-aanpak' in het MAB (De Bruin, 1989, Buisman \& Ten Wolde, 1989, Kinds \& Van Kollenburg, 1990, Krom, 1989 en Tuinsma, 1989) alsmede Van Barneveld \& Van Densen, 1990, Van Dijk, 1989 (2x), Emanuels \& Wallage, 1990, Limperg Instituut, 1990 en Ten Wolde, 1989. 3 De problematiek bij de gemeentelijke overheid werd onlangs besproken in de artikelen van Van Oorschot (1990) en Koolen \& Wiersma (1990).

4 Volgens de ontwerp vijfde wijziging Comptabiliteitswet (wetsontwerp 21471, kamerstuk 2) zal deze bepaling worden verplaatst naar artikel 51 lid 1 en komen te luiden: 'De Algemene Rekenkamer onderzoekt het door de ministers gevoerde financiële beheer en de jaarlijkse financiële verantwoordingen daarover.'

5 In de ontwerp Vijfde wijziging Comptabiliteitswet wordt dit artikel 66 vervangen door artikel 51 (Wetsontwerp 21471, kamerstukken nr. 2, 6 maart 1990) van paragraaf 2 'rechtmatigheidsonderzoek'. Inhoudelijk wordt de rechtmatigheidscontrole hierdoor echter niet wezenlijk veranderd. 6 Dit moet niet worden verward met de in 7 te bespreken toerekening van de controletolerantie aan begrotingsartikelen. Daar gaat het om de verdeling over de begrotingsartikelen van de inspanningen nodig voor een oordeel over het geheel. Hier echter gaat het om een additioneel oordeel per begrotingsartikel. 7 Daarnaast speelt het probleem dat bij sommige departementen, zoals Defensie en Verkeer en Waterstaat, sprake is van een omvangrijk bedrag aan aangegane langlopende verplichtingen die pas in latere jaren tot uitgaven leiden. Indien voor hen in een bepaald jaar het totaal van de aangegane verplichtingen plus ontvangsten een betere omvangsbasis is dan het totaal van uitgaven en ontvangsten, bijvoorbeeld omdat de totale uitgaven, vergeleken met de aangegane verplichtingen extreem laag zijn zouden zij kunnen kiezen voor aangegane verplichtingen + ontvangsten (of verworven rechten) als omvangsbasis.

$8 \mathrm{Bij}$ sommige departementen worden tevens accountantsverklaringen afgegeven bij de verantwoordingen van departementsonderdelen. Hier kan in het licht van het feit dat het een deelverantwoording, hoofdzakelijk voor intern gebruik, betreft eventueel een iets hoger tolerantiepercentage worden gehanteerd, zij het dat deze tolerantie niet al te hoog mag worden gesteld omdat anders de deugdelijke grondslag voor een accountantsverklaring dreigt weg te vallen. 